\title{
光トラップ法を用いたボース・アインシュタイン凝縮体の生成
}

\author{
高橋 義朗
}

京都大学大学院 理学研究科 (下606-8502 京都市左京区北白川追分町)

(独)科学技術振興機構, CREST ( ₹332-0012 埼玉県川口市本町4-1-8)

\section{Formation of Bose-Einstein Condensates with Optical Trapping Method}

\author{
Yoshiro TAKAHASHI \\ Graduate School of Science, Kyoto University, Oiwakecho, Kitashirakawa, Sakyo-ku, Kyoto 606-8502 \\ JST CREST, 4-1-8, Honcho, Kawaguchi, Saitama 332-0012
}

(Received February 18, 2004)

\begin{abstract}
We have achieved Bose-Einstein condensation of rubidium $\left({ }^{87} \mathrm{Rb}\right)$ and ytterbium $\left({ }^{174} \mathrm{Yb}\right)$ atoms by optical trapping method. After collecting the atoms in the magneto-optical trap, we have performed evaporative cooling for the atoms in the optical trap. The Time-Of-Flight signals clearly showed the anisotropic expansion of the atom cloud, which is the evidence of the formation of the condensates. Along with these our works, we review the recent experiments on Bose-Einstein condensation with optical trapping method.
\end{abstract}

Key Words: Bose-Einstein condensation, Optical trapping, Ytterbium atoms

1. はじめに

量子統計力学によると, 理想ボース粒子系は, 位相空 間密度 $\rho=n \lambda_{\mathrm{dB}}{ }^{3}=n h^{3} /\left(2 \pi m k_{\mathrm{B}} T\right)^{3 / 2}$ が2.61を超えたときに, 量子相転移を起こし, 基底状態に巨視的な数の粒子が落 ち込む.これがボース・アインシュタイン凝縮である. ただし, $n$ は原子数密度, $\lambda_{\mathrm{dB}}=h /\left(2 \pi m k_{\mathrm{B}} T\right)^{1 / 2}$ は熱的ドブロ イ波長， $T$ は温度を表し， $h, m, k_{\mathrm{B}}$ はそれぞれ，プランク 定数, 原子質量, ボルツマン定数である。1980年代から 発展してきたレーザー冷却の技術を活用することで, 1995年にアルカリ金属のルビジウム $(\mathrm{Rb})$ 原子気体のボー ス・アインシュタイン凝縮 (BEC) が実現された ${ }^{1)}$.その 後, 同じアルカリ金属のナトリウム $(\mathrm{Na})^{2)}$, リチウム $(\mathrm{Li})^{3)}$, カリウム $(\mathrm{K})^{4)}$ の各原子のBEC も実現し, 様々な興 味深い研究が猛烈な勢いで展開され，それに対して2001 年度のノーベル物理学賞が希薄気体アルカリ原子のBECの 実現とその基礎研究に対して与えられたことは記憶に新 しい.ささらに水素原子 $(\mathrm{H})^{5)}$ や準安定状態のスピン3重項状 態へリウム原子 $\left(\mathrm{He}^{*}\right)^{6}$ )についてもBECは実現している. また，フェルミ粒子に対しての量子縮退状態であるフェ ルミ縮退状態もカリウム原子7), リチウム原子8) に対して 実現している.

以上に挙げた原子のBECやフェルミ縮退は, レーザー 冷却法のみによって達成されたわけではない. 光の吸収 を伴うレーザー冷却法は, 数 $\mu \mathrm{K}$ 程度までの低温や $10^{12}$ $\mathrm{cm}^{-3}$ 程度の原子密度の原子集団を得るのには大变有効な方
法であるが，それ以上の低温や高密度を得る方法として は, 都合が悪い。まず, 温度の限界は, 単一光子の反跳 によって決まり，この限界温度 $T=(\hbar k)^{2} /\left(2 m k_{\mathrm{B}}\right)$ は通常数 $100 \mathrm{nK}$ 程度になる。 また, 高密度集団に共鳴に近い光を入 射したときには，トラップ中の原子の自然放出光を別の 原子が吸収してしまい，原子間に実効的な反発力が働 き，更なる高密度化が抑制されてしまう。また同時に， 光誘起の原子間衝突が起こり, 加熱や原子がトラップか ら逃げる原因となってしまうため, 極めて都合が悪い. そのため, 以上に挙げたアルカリ原子では, あらかじめ レーザー冷却法により低温・高密度にした原子集団を, 空間的に不均一な磁場と原子の磁気モーメントの相互作 用による磁気トラップ法を用いて長時間トラップし, そ こで高周波磁場によるスピン反転を利用して, 高温の原 子を選択的にトラップから逃がすことによる冷却法，い わゆる蒸発冷却法により, 通常 $100 \mathrm{nK}$ 程度のBECやフェル ミ縮退への転移温度を達成している。 すなわち, 最後の 段階になって，レーザー冷却の利用をあきらめる，とい う選択をしたのである。

一方, 最近になって, 全光学的方法によって, 原子の BECやフェルミ縮退を実現できることが報告されている. これは, 蒸発冷却を採用したうえで, そのトラップの「器」 として光トラップを利用するというものである.すなわ ち，レーザー冷却により予備冷却したのち，磁気トラッ プではなく, 光によるトラップに導入し, そこで光強度 を徐々に低くしていくことにより蒸発冷却を行い, 量子 
縮退領域に到達している。これまでに， ${ }^{87} \mathrm{Rb}$ 原子 $\mathrm{BEC}^{9)}$, $\mathrm{Cs}$ 原子 $\mathrm{BEC}^{10)}$, $\mathrm{Li}$ 原子フェルミ縮退 ${ }^{11)}$, そして2電子系原 子であるイッテルビウム $(\mathrm{Yb})$ 原子のスピンの無い状態で のBECが筆者のグループにより実現されている12).さら に最近は, Li分子のBECの全光学的生成13) も報告されてい る.このように, 希薄原子気体の量子縮退研究の分野で は，2001年度のノーベル物理学賞以降も，画期的な成果 の報告が後を絶たないが，これを支えている技術の一つ が光トラップ法であり，本論文ではこれについて，我々 の研究結果も交えて解説したい.

\section{2. 光トラップ}

本章では, 光トラップについての基本事項をまとめて おくことにする14).

まず，話を簡単にするために，共鳴周波数 $\omega_{0}$ の2準位原 子に周波数 $\omega_{\mathrm{L}}$ の光を入射した場合を考える．このとき， 光によるポテンシャルは,

$$
U=-\hbar \Delta / 2 \times \ln \left[1+\Omega^{2} / 2\left(\Delta^{2}+(\gamma / 2)^{2}\right)\right]
$$

と表すことができる。ここで， $\Delta=\omega_{0}-\omega_{\mathrm{L}}$ は離調， $\Omega$ はラ ビ周波数， $\gamma$ は自然幅をそれぞれ表す。これは，光による 原子のエネルギー準位のシフトでもあり，ライトシフト とも呼ばれている。また，正弦波の光電場によるシフト でもあり，ACシュタルクシフトとも呼ばれる。ここで, 離調 $\Delta=\omega_{0}-\omega_{\mathrm{L}}$ が原子の自然幅 $\gamma$ よりも十分大きい場合に ついては，(1)式は

$$
U \cong-\hbar \Omega^{2} / 4 \Delta=-\hbar \gamma^{2} / 8 \Delta \times\left(I / I_{s}\right)
$$

となる。ここでIは光強度， $I_{\mathrm{s}}$ は飽和光強度で，

$$
2 \Omega^{2} / \gamma^{2}=I / I_{s}
$$

の関係がある。

このような場合を Far-Off Resonant optical Trap, 略して FORTと呼ぶ. ほとんどの光トラップの実験は，この条件 で行われている。

また，この表式から明らかなように，赤方離調 $\Delta>0$ の 場合には, 光ポテンシャルは負になる。したがって, ガ ウスビームをレンズ等でフォーカスさせるだけで, 強度 が最も高い焦点に原子をトラップすることが可能にな る. 青方離調 $\Delta<0$ の場合には, 光ポテンシャルは正にな り，原子をトラップするには工夫が必要になる。ボーズ 凝縮生成に使われているのは, 単純な赤方離調 $\Delta>0$ の場 合のみであり, 以下，この場合に限って話を進める。

FORTでは非共鳴な光を用いているからといっても, 光 の吸収はゼロではない.一般に, 光散乱レートは,

$$
\begin{aligned}
& \Gamma_{\mathrm{sc}}=3 \pi c^{2} /\left(2 \hbar \omega_{0}^{3}\right)\left(\omega_{\mathrm{L}} / \omega_{0}\right)^{3}\left\{\gamma /\left(\omega_{\mathrm{L}}-\omega_{0}\right)+\gamma /\left(\omega_{\mathrm{L}}+\omega_{0}\right)\right\}^{2} \\
& \quad \times I
\end{aligned}
$$

で与えられ，これにより，加熱やトラップロスを引き起 こす. 深いポテンシャル中で長い時間を要する蒸発冷却 のときには特に注意が必要である.

一方, 炭酸ガスレーザーによる光トラップは, 多少事
情が異なる。この場合は，特に準静的光トラップ (QUEST) とよばれている。炭酸ガスレーザーの波長は $10.6 \mu \mathrm{m}$ と非常に長い. 可視領域の共鳴線に対しては，一 林も長いため, $\Gamma_{\mathrm{sc}}$ の表式において, $\left(\omega_{\mathrm{L}} / \omega_{0}\right)^{3}$ の項が $10^{-3}$ の オーダーになり, このため, 炭酸ガスレーザーによる光 トラップQUESTでは, 光散乱レートは無視できるほど小 さいという大きな利点がある。

光トラップの形状については, 用いた光ビームの性質 に依存する，Z軸方向に進行するパワーPのガウスビーム の光強度 $I(z, r)$ は，一般に次式で表される，

$$
I(z, r)=2 P /\left(\pi w(z)^{2}\right) \exp \left(-2 r^{2} / w(z)^{2}\right) .
$$

ここで, $r$ は光ビームの中心軸からの動径方向の距離で, $w(z)$ は

$$
w(z)=w_{0}\left\{1+\left(z / z_{R}\right)\right\}^{1 / 2}
$$

で与えられる, 強度が $1 / \mathrm{e}^{2}$ になる半径であり, $z=0$ で最小 值 $w_{0}$ (ビームウエスト)をとる。また， $z_{\mathrm{R}}=\pi w_{0}^{2} / \lambda$ はレー リー長である。したがってポテンシャル $U(z, r)$ は，(2)式 と(4)式より

$$
U(z, r)=U_{0} \exp \left(-2 r^{2} / w(z)^{2}\right)
$$

で与えられ，ここでピークポテンシャル $U_{0}$ は,

$$
U_{0}=-\hbar \gamma^{2} P /\left(4 \Delta I_{s} \pi w(z)^{2}\right)
$$

で与えられる。 また，トラップの中心付近 $r=0, z=0$ で は, 式 (6)は, $U(z, r)=U_{0}\left\{1-2\left(r / w_{0}\right)^{2}-\left(z / z_{R}\right)^{2}\right\}$ と展開で き, 調和ポテンシャルと近似できる。したがって, ト ラップ周波数は動径方向 $\omega_{\mathrm{r}}$ および軸方向 $\omega_{\mathrm{z}}$ について,

$$
\omega_{r}=\left(4 U_{0} / m w_{0}^{2}\right)^{1 / 2}, \quad \omega_{z}=\left(2 U_{0} / m z_{R}\right)^{1 / 2}
$$

で与えられる。これらのトラップ周波数は，パラメト リック共鳴現象を利用して実験的に求めることができ る. 基準振動数 $\omega て ゙$ 単振動する系のポテンシャルを振動数 $\omega^{\prime}$ で微少変調させたときには, $\omega^{\prime}=2 \omega / n$ のときに系は不 安定になり，トラップされた原子は加熱およびトラップ ロスとなる．ここで $n=1 ， 2 ， 3 ， \ldots$ である. Fig. 1に我々 が， ${ }^{87} \mathrm{Rb}$ 原子を炭酸ガスレーザーでトラップしたときのパ ラメトリック共鳴の信号を示す. $n=1$ おび2の信号が観 測されている。これから, 変調時の強度減少を考慮し て, $\omega_{\mathrm{r}}=2 \pi \times 920 \mathrm{~Hz}$ と求めることができ, これは予想值 とほぼ一致した結果であった。

このようにして原子を光トラップし, 光強度を音響光 学変調器 $(\mathrm{AOM})$ 等を用いて徐々に下げることにより, 蒸 発冷却を行う。磁気トラップされた原子の蒸発冷却は, 高周波磁場を印加しその周波数を徐々に下げていくこと により行うため, 蒸発冷却の間, 束縛の強さは変化しな い.ところが，光トラップにおいては，上で見てきたと おり, 光強度を下げるとトラップ周波数も減少してしま うため, 都合が悪い. そのため, 蒸発冷却時の光強度を 減少させる時系列はより注意が必要になる。Thomasら は，光トラップ中での蒸発冷却を効率よく行うにはどの ような時間依存性で光強度を下げていけばいいのかを議 


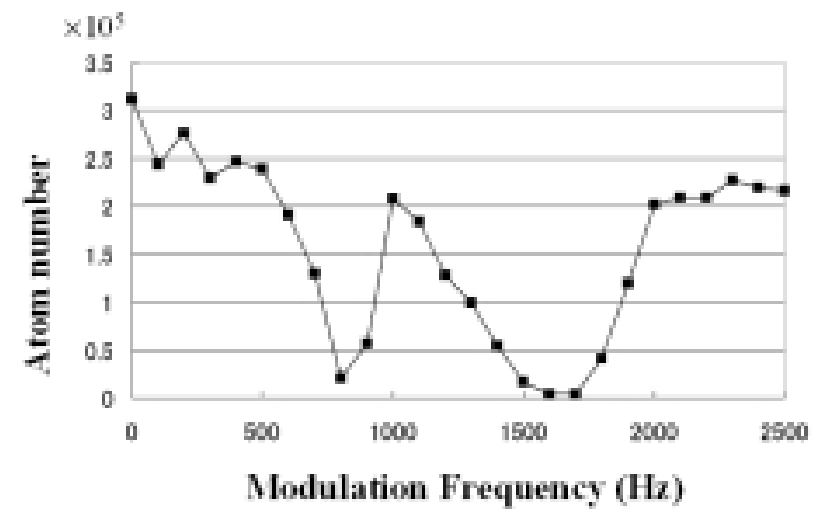

Fig. 1 Parametric resonaces of the optically trapped ${ }^{87} \mathrm{Rb}$ atoms. The trap loss is caused by modulation of the trapping potential.

論し15)，それは彼らの実験結果ともほぼ一致している。 蒸発冷却の過程で，原子間衝突による熱平衡化を利用す

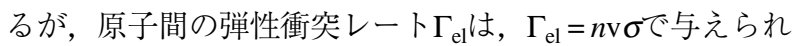
る。ここでのは衝突断面積, $\mathrm{v}$ は平均速度である。これか ら分かるように，高密度な方が，言い換えれば，トラッ プ周波数が高い方が， $\Gamma_{\mathrm{el}}$ は高い值をとることになる。一 般に光トラップでは磁気トラップに比べて, 高いトラッ プ周波数を実現できるため，光強度を下げることによる トラップ周波数の低下は致命的にはならず, 蒸発冷却の 最終段階に扔いても高い弾性衝突レート $\Gamma_{\mathrm{el}}$ を維持でき, しかも比較的短時間で蒸発冷却を行うことが可能とな る。これは, 実験に用いる真空チャンバーの真空度に対 する制限を大いに緩和する。

\section{3. 全光学的ボース凝縮生成実験}

\section{$3.1 \mathrm{Rb}$ 原子}

本章に㧍いて，これまでに報告されている全光学的 ボース凝縮生成実験を原子ごとにみていくことにしょ う.

初めて全光学的にボース凝縮体を生成させることに成 功したのは, ジョージア工科大学のM. Chapmanらのグ ループで，用いた原子は ${ }^{87} \mathrm{Rb}$ 原子であった ${ }^{9)} .{ }^{87} \mathrm{Rb}$ 原子 は, 散乱長 $\mathrm{a}=5.8 \mathrm{~nm}$ と大きく, したがって弾性衝突断面 積 $\sigma=8 \pi \mathrm{a}^{2}$ も大きい。一方, 非弹性衝突レートは小さく, 蒸発冷却にとっては非常に適したサンプルである。筆者 のグループでも最近, 全光学的に ${ }^{87} \mathrm{Rb}$ 原子のボース凝縮体 を生成させることに成功したので，それをもとに以下説 明していきたい。

\section{1 .1 磁気光学トラップ}

まず, 磁気光学トラップ $(\mathrm{MOT})$ 法により109個程度の多 数個の原子を超高真空中に集めることから実験は始ま る。そのためによく採られる手法はダブルMOTと呼ばれ る方法で，これは比較的低真空領域で行うMOTから超高 真空領域で行うMOTに原子を移送させるものである. 我々は, MOT光のビーム直径を約 $5 \mathrm{~cm}$ と広くすることで 超高真空領域で行うMOTのみで109個の原子を集めること
に成功した。 その後, 基底状態の別の超微細準位に原子 を移して，さらに低温・高密度化を行う。これはダーク MOTと呼ばれている，後述する光トラップビームも同時 に入射して扔り，このダークMOT時に原子は光トラップ へ移行される。

\section{1 .2 光トラップ}

光トラップ用光源として炭酸ガスレーザー $(10.6 \mu \mathrm{m})$ を 用いた。このレーザー光を半径約 $50 \mu \mathrm{m}$ までフォーカス し，ダークMOTにトラップされた原子集団に空間的に重 ねた． 50 Wの出力を，ビームスプリッターで2つに分け， それぞれのビームにAOMを挿入し，強度を独立に変えら れるようにした．この2本の光をそれぞれのフォーカス点 で重ねることで，いわゆる，交差型光トラップを実現し た。このときトラップ深さは約 $100 \mu \mathrm{K}$ で，平均トラップ 周波数は $2 \pi \times 780 \mathrm{kHz}$ ，原子数は約 $2 \times 10^{6}$, 原子密度は 約 $1.8 \times 10^{14} \mathrm{~cm}^{-3}$ ，温度は約 $25 \mu \mathrm{K}$ ，であった。特に， $10^{14}$ $\mathrm{cm}^{-3}$ という原子密度は，予想よりも極めて高いものであっ た。最初に述べた通り, MOT光が存在しているときに は，このような高密度原子集団は形成されないはずであ る. Chapmanらが文献9)に打いて予想するように, 何か, 極めて特殊な効果が働いているのであろうか? 我々は, 遅延交差型光トラップと我々が名づけた方法により，こ れは原子間衝突によって生成されていることを明らかに した ${ }^{16)}$. この遅延交差型光トラップ法では, 最初は単一 の光ビームによって原子をトラップする，その後， $30 \mathrm{~ms}$ 程度の遅延時間だけ待って，もう一方の光ビームを入射 して交差型光トラップを形成する。これにより, 交差領 域での非常に高い原子密度が，MOT光を消した後に光卜 ラップ中で原子間の衝突によって達成されうるのか否か を，明らかにすることができる．最近行った我々の実験 で, 原子間衝突によって高密度原子集団が達成されてい ることを明確に示す結果を得ることができた。この実験 は，トラップ形状を変形させることにより位相空間密度 を上昇させている，とみることもできる．

\section{1 .3 蒸発冷却}

このように高密度光トラップは実現したが, 温度が比 較的高いため, 位相空間密度は約 $3 \times 10^{-3}$ 程度に留まって いる，さらに位相空間密度を上昇させるために光トラッ プ中で蒸発冷却を行った。蒸発冷却では原子間衝突を利 用するため，比較的長い時間を要する。磁気トラップを 用いた場合では通常1分程度かけて, 徐々に泠却を行う。 光トラップ中では, 最初の段階から高密度であるため, 比較的短時間で済むことになるが，それでも長いトラッ プ時間を確保することは重要である. 我々の実験では, 光トラップ中での寿命 10 秒程度を達成することができ た。

前述した交差型光トラップの配置で, 約4秒かけて水平 および垂直の光強度を徐々に下げることで蒸発冷却を 行った。これにより，温度は約 $800 \mathrm{nK}$ 以下に冷却すること ができ，約 $2 \times 10^{4}$ 個の原子からなるBECを生成することが できた。 
実験結果をFig. 2に示す。これは飛行時間 (TOF) 信号と 呼ばれるものであり, 蒸発冷却を施した後に光トラップ から開放し，一定時間自由運動させた後の空間分布を測 定したものである。したがって，光トラップ解放直前の 運動量分布を反映したものになる。非等方な分布が， BEC の証拠であり，BECの転移前では，温度は低くても等方的 である。

\section{$3.2 \mathrm{Yb}$ 原子}

我々はここ数年, 永久電気双極子モーメントの探索に よる時間反転対称性の破れの検証を目的に17)，広く用い られてきたアルカリ原子ではなく, 希土類のイッテルビ ウム $(\mathrm{Yb})$ 原子のレーザー冷却の研究を行ってきた ${ }^{18)}$. $\mathrm{Yb}$ 原子はパリティー非保存の研究19）や原子時計への応用20) など幅広く興味を持たれている原子である，Yb原子の レーザー冷却研究を推し進めていった結果, 最近, 我々 はこの $\mathrm{Yb}$ 原子のBECを全光学的に生成することに成功し た ${ }^{12)}$ 。これは2電子系原子のスピン1重項状態については じめてのBEC成功例であり，このspinless BECには様々な 応用が期待されている。

\section{2 .1 磁気光学トラップ}

実験の第一段階はスピン禁制の異重項間遷移 $\left({ }^{1} \mathrm{~S}_{0}-{ }^{3} \mathrm{P}_{1}\right)$ を 用いたMOTである ${ }^{21)}$. Yb原子は，アルカリ土類原子と同 様な2電子系の原子であり, Fig. 3のようなエネルギー準位 構造を持つ。 ${ }^{3} \mathrm{P}_{1}$ 準位の輻射寿命は $875 \mathrm{~ns}$ であり，アルカリ 原子のD線などに比べて1桁以上長いため, ドップラー限 界温度が $4.4 \mu \mathrm{K}$ と非常に低いことが特徵である。 ${ }^{174} \mathrm{Yb} に$ 対して実験を行った結果は, 原子数は約 $10^{8}$ 個, 原子密度 は約 $10^{12} \mathrm{~cm}^{-3}$, 温度は約 $10 \mu \mathrm{K}$, トラップ寿命は約 100 秒, であった。この段階で，位相空間密度は $10^{-5}$ となってお り，BECを作るのには，かなりいい初期条件となってい る.

\section{2 .2 光トラップ}

$\mathrm{Yb}$ 原子の基底状態には電子スピンがないために, 磁気 トラップを行うことはできない，したがって，Yb原子の 保存力によるトラップを実現するには，光によるトラッ プ(FORT)が唯一の方法である。我々の実験では，2本の FORT光をそれぞれのフォーカス点で重ねることで，いわ

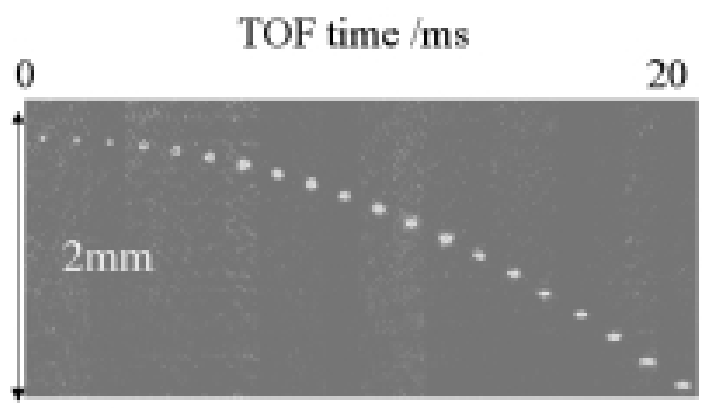

Fig. 2 Time-Of-Flight (TOF) signal of the ${ }^{87} \mathrm{Rb}$ atoms after evaporative cooling. The anisotropic expansion is the evidence of the BEC.

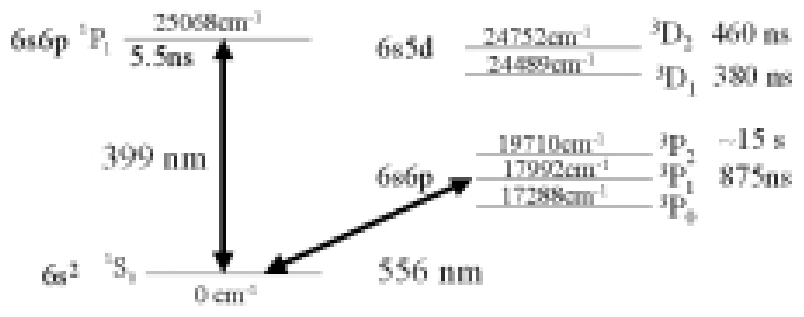

Fig. 3 Energy level structure of $\mathrm{Yb}$ atom.

ゆる，交差型FORTを実現した16)。このときトラップ深さ は約 $1 \mathrm{mK}$ で, 原子数は約 $10^{6}$, 原子密度は約 $10^{14} \mathrm{~cm}^{-3}$, 温 度は約 $100 \mu \mathrm{K}$ ，であった。 $10^{14} \mathrm{~cm}^{-3}$ という原子密度は，や はり極めて高いものであり，前述の ${ }^{87} \mathrm{Rb}$ 原子同様，これは 原子間衝突によって生成されていることを我々は明らか にした16).

さらに，我々の実験では 10 秒程度の光トラップ中での 寿命を得ることができた。

\section{2 .3 蒸発冷却}

最終的なBEC生成の実験セットアップをFig. 4に示す. 当初, FORT光を水平面内で交差させた配置で実験を行っ ていたが，鉛直面内 $(1$ 本は水平，もう1本は鉛直)で交差さ せた配置に改良した。後者の配置では重力の影響を利用 することで，非交差領域に原子が留まってしまうことを 回避できる，この配置で，FORT光強度を徐々に下げるこ とで交差型FORT中の ${ }^{174} \mathrm{Yb}$ 原子に対して蒸発冷却を行っ た。蒸発泠却においてポテンシャルを下げていく様子を Fig. 5に示した。これにより，約 $5 \times 10^{3}$ 個の原子からなる BECを生成することができた。

TOF信号をFig. 6に示す. トラップ直後では縦長であっ た分布が，徐々に横長になっていくのが分かる。また， 転移温度近傍での原子の運動量分布を示したのが，Fig. 7 である。転移点では, 二つの構造, すなわち熱原子の分 布とより狭いBEC原子の分布が共存していることが分か る.これも BEC相転移が起こっていることの証拠である.

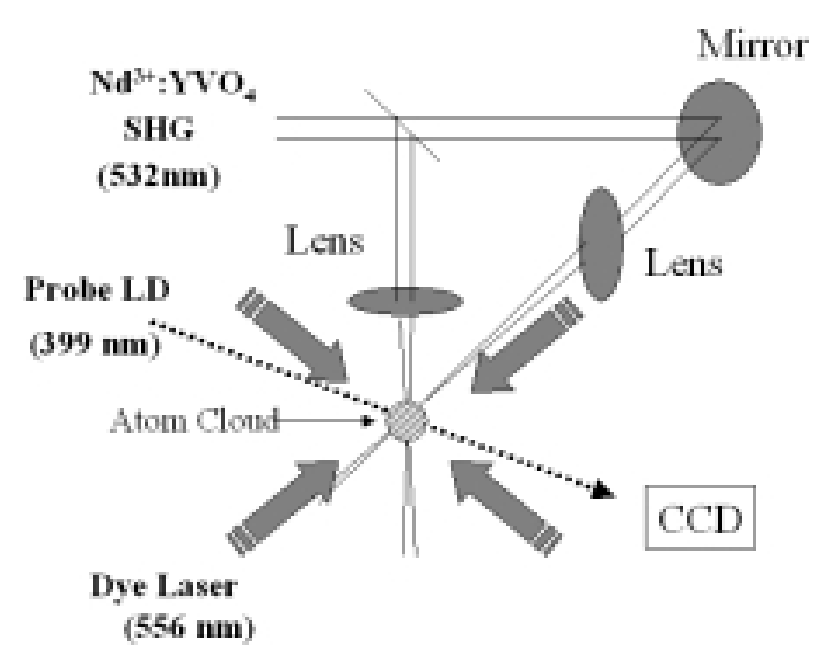

Fig. 4 Experimental setup of all-optical formation of BEC of ${ }^{174} \mathrm{Yb}$ atoms. 


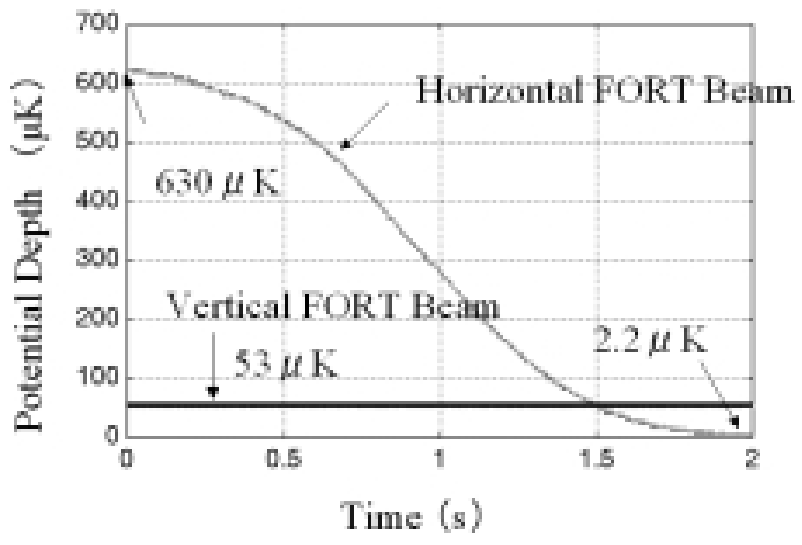

Fig. 5 Temporal changes of the FORT potential depths during the evaporative cooling.

\section{TOF time $/ \mathrm{ms}$}

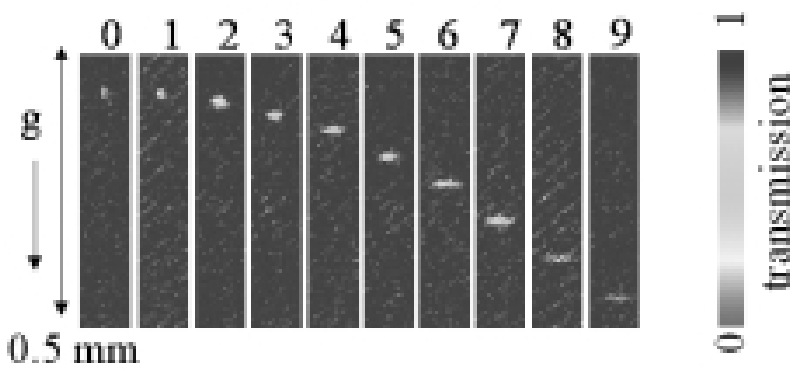

Fig. 6 TOF signal of the ${ }^{174} \mathrm{Yb}$ atoms after evaporative cooling. The anisotropic expansion is the evidence of the $\mathrm{BEC}$ of the ${ }^{174} \mathrm{Yb}$ atoms.

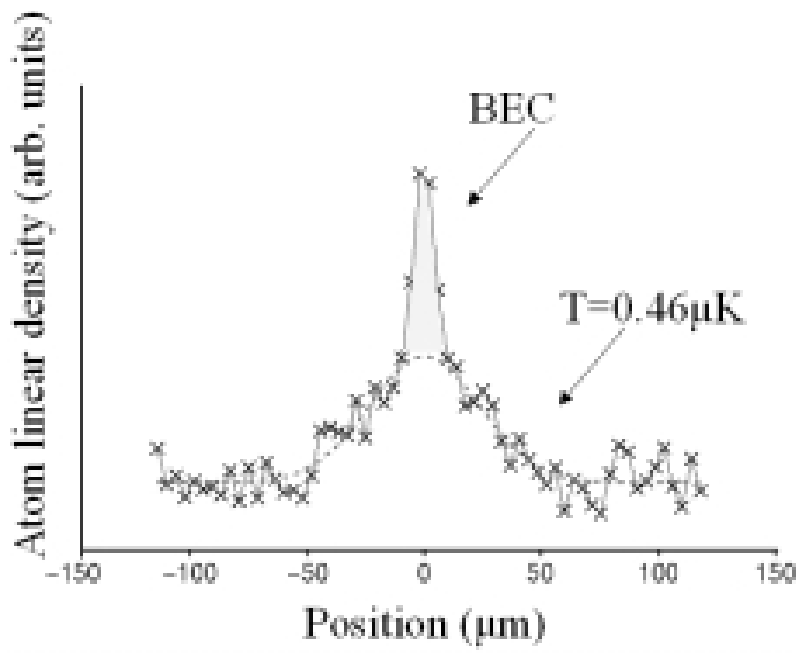

Fig. 7 Bimodal atom density distribution near the BEC phase transition.

\subsection{Cs原子}

Cs原子は，その超微細構造間の遷移が原子時計として 用いられ，また，原子番号が大きいために相対論的効果 が顕著であることから parity非保存実験などに用いられて いる.レーザー冷却の対象としても当初から用いられて おり, 当然, BEC実現への取り組みも早い段階から複数の 研究機関で行われてきていた。しかし, 磁場の広い範囲 で，非弾性散乱レートが非常に大きいことが明らかにな
り，磁気トラップを用いる方法では，蒸発冷却が極めて 困難であることが認識されるようになった。ところが, 昨年, R. Grimmのグループは，光トラップの方法により この困難を克服し, Cs 原子のBECに成功したことを報告 した10).

\subsubsection{2段階の光トラップ}

彼らは，ラマンサイドバンド冷却法により $1 \mu \mathrm{K}$ で冷 却された, 密度 $10^{11} \mathrm{~cm}^{-3}$ の $\mathrm{Cs}$ 原子約 $10^{7}$ 個を, まず, 交差 型炭酸ガスレーザーに導入した。原子密度が低いため, 蒸発冷却の効率も悪くなってしまうのを, Feshbach共鳴 ${ }^{22}$ を用いて，磁場を $75 \mathrm{G}$ にすることより散乱長を $\mathrm{a}=1200$ $\mathrm{a}_{0}$ にまで増大させて，10秒間，蒸発冷却を行った。ここで $\mathrm{a}_{0}$ はボーア半径である。 その結果，位相空間密度は，導入 時の $10^{-4}$ から $10^{-3}$ にすることに成功した。光トラップで は，磁場は自由に変えられることを有効に用いている。 磁気トラップでも磁場を変えることは可能であるが，卜 ラップの閉じ込めの強さも同時に変わってしまうのが難 点である。その後，5秒かけて炭酸ガスレーザートラップ から波長1.064 $\mu \mathrm{m}$ のファイバーレーザートラップに原子を 移行させ， $10^{12} \mathrm{~cm}^{-3}$ ほどの高密度にして, 位相空間密度 10-2を達成している。 その後，17秒かけてファイバーレー ザー強度を徐々に下げることにより，BECを達成してい る。ここで, 原子集団が高密度になるため磁場の值を $23 \mathrm{G}$ まで下げて, 散乱長を $300 \mathrm{a}_{0}$ まで小さくして, 非弾性散乱 を抑えるという工夫をしている，このように，光トラッ プとFeshbach共鳴の組み合わせにより, 散乱長を自由に制 御することを可能にしたことが成功の原因である。

\section{$3.4 \mathrm{Li}$ 原子}

この光トラップとFeshbach共鳴の組み合わせによる散乱 長の制御は，フェルミ粒子である ${ }^{6} \mathrm{Li}$ に対しても極めて有 効であり, Thomasらは, 炭酸ガスレーザーを用いて, 全 光学的に ${ }^{6} \mathrm{Li}$ 原子のフェルミ縮退状態を実現し11), さらに 原子相互作用を強相関の領域にまで到達させることに成 功している23). また, Grimmらは, 全光学的に ${ }^{6} \mathrm{Li}$ 原子の フェルミ縮退状態を生成したのち, Li分子のBECの生成に も成功している13).

\section{4. 今後の展望}

光トラップ法を用いたボース凝縮生成実験について概 観してきた。多少抽象的な言い回しになるが，今後の展 望について簡単に触れてみたい. 光トラップ法は, 磁気 トラップに比べて, 様々な操作が可能になるため, これ までBEC到達が絶望的，もしくは極めて困難であった原子 も，様々な工夫によってBECを生成することが可能になる のは，容易に想像がつく，例えば，磁気副準位の自由度 を回復させてFeshbach共鳴により散乱長を制御することが 可能になるため， ${ }^{85} \mathrm{Rb}$ 原子のBECもより簡単に生成できる ようになるかもしれない.また，アルカリ土類的原子の ${ }^{3} \mathrm{P}_{2}$ 状態も光卜ラップの利用により $\mathrm{BEC}$ 河能になるかも しれない。この系では，磁気トラップすることが可能な 
スピン状態が非常に大きなスピンフリップによる非弾性 散乱レートをもつことが，問題点として指摘されている が, 光トラップ中ではスピン状態を自由に選択できるた め，この問題を回避することが可能となるかもしれな い.

また，光格子にBECやフェルミ縮退した原子を導入す るとさらに興味深い実験が可能になる. 特に, Yb原子に は，準安定の光励起状態 ${ }^{3} \mathrm{P}_{2},{ }^{3} \mathrm{P}_{0}$ 状態が存在し，基底状態と の間には，弱い光遷移が可能である。この遷移は，とも にmHz台の非常に狭い線幅を有しており，光周波数標準と して有望視されている20,24)．従来は，低温の熱原子集団を 用いて実験が行われていて，熱運動が測定精度を制限し ている. BEC, 特に, 光格子中の各格子に1原子ずつ配置 されたモット絶縁相にある $\mathrm{BEC}^{25)}$ では，原子間相互作用 もなく, また各原子は各格子ポテンシャルの振動基底状 態にのみあるため，仮にいわゆるラムディッケ領域に束 縛されてなくとも，測定精度の向上が望めるであろう。 また，量子シミュレーターへの応用も大変重要である。 光格子中のBECを用いてモット絶縁相と超流動状態の量子 相転移を観測した実験25) は非常に印象的であったが, フェルミ縮退した原子集団を光格子に導入した系を生成 して，これを固体の結晶格子中の強相関電子系とみな し, そのシミュレーターとする研究は, 最近非常に注目 されている，BCS転移温度も高くなることも予想されてお り，その点でも興味深い26).

\section{謝 辞}

本論文で紹介した筆者のグループの実験のうち，Yb原 子については, 大学院生の高須 洋介, 牧賢一, 加藤豊, 山口 敦史の諸氏, Rb原子については, 大学院生の小林 淳，押切 洋平，泉勇気の諸氏との共同研究であり，また ともに藪崎 努教授および熊倉光孝助手との共同研究でも あるので，ここに深く感謝したい. 本研究は文科省科学 研究費 $(11216203 ， 11640394 ， 11304023 ， 13640403$, $15635001,15340134,15654055$ ), 通信総合研究所(現 情報通信研究機構), 総務省戦略的情報通信開発推進制度 の支援を頂いたのでここに深く感謝する。

\section{参考文献}

1) M. H. Anderson, J. R. Ensher, M. R. Andrews, C. E. Wieman, and E. A. Cornell: Science 269 (1995) 198.

2) K. B. Davis, M.-O. Mewes, M. R. Andrews, N. J. van Druten, D. S Durfee, D. M. Kurn, and W. Ketterle: Phys. Rev. Lett. 75 (1995 3969

3) C.C. Bradley, C. A. Sackett, J. J. Tollett, and R. G. Hulet: Phys. Rev. Lett. 75 (1995) 1687

4) G. Modugno, G. Ferrari, G. Roati, R. J. Brecha, A. Simoni, and M. Inguscio: Science 294 (2001) 1320.

5) D. G. Fried, T. C. Killian, L. Willmann, D. Landhuis, S. C. Moss, D. Kleppner, and T. J. Greytak: Phys. Rev. Lett. 81 (1998) 3811.

6) A. Robert, O. Sirjean, A. Browaeys, J. Poupard, S. Nowak, D. Boiron, C. I. Westbrook, and A. Aspect: Science 292 (2001) 461

7) B. DeMarco and D. S. Jin: Science 285 (1999) 1703

8) A. G. Truscott, K. E. Strecker, W. I. Maclenxander, G. B. Patridge, and R. G. Hulet: Science 291 (2001) 2570

9) M. D. Barrett, J. A. Sauer, M. S. Chapman: Phys. Rev. Lett. 87 (2001) 010404

10) T. Weber, J. Herbig, M. Mark, H.-C. Nagerl, and R. Grimm: Science 299 (2003) 232.

11) S. R. Granada, M. E. Gehm, K. M. O'Hara, and J. E. Thomas: Phys Rev. Lett, 88120405 (2002).

12) Y. Takasu, K. Maki, T. Takano, K. Komori, K. Honda, M. Kumakura T. Yabuzaki, and Y. Takahashi: Phys. Rev. Lett. 91 (2003) 040404.

13) S. Jochim, M. Bartenstein, A. Altmeyer, G. Hendl, S. Riedl, C. Chin, J. Hecker Denschlag, and R. Grimm: Science 302 (2003) 2101.

14) R. Grimm, M. Weidemuller, and Y. B. Ovchinikov: Adv. At. Mol. Opt. Phys. 42 (1999) 95

15) K. M. O'Hara, M. E. Gehm, S. R. Granada, and J. E. Thomas: Phys Rev. A 64 (2001) 051403.

16) Y. Takasu, K. Honda, K. Komori, M. Kumakura, Y. Takahashi, T. Yabuzaki: Phys. Rev. Lett. 90 (2003) 023003.

17) Y. Takahashi, M. Fujimoto, T. Yabuzaki, A. Dilip, M. K. Samal, and B. P. Das: in Proc. CP Violation and its Origin, edited by K. Hagiwara (KEK Reports, Tsukuba, 1997).

18) 高橋 義朗, 薮崎努：日本物理学会誌 57 No.6 (2002) 413 .

19) D. DeMille: Phys. Rev. Lett. 74 (1997) 4165.

20) J. Hall, M. Zhu, and P. Buch: Opt.Soc. Am. B6 (1989) 2194.

21) T. Kuwamoto, K. Honda, Y. Takahashi, and T. Yabuzaki: Phys. Rev. A. 60 (1999) R745.

22) S. Inouye, M. R. Andrews, J. Stenger, H.-J. Miesner, D. M. StamperKurn, and W. Ketterle: Nature 392 (1998) 151

23) K. M. O'Hara, S. L. Hemmer, M. E. Gehm, S. R. Granada, and J. E. Thomas: Science 298 (2002) 2179.

24) H. Katori, M. Takamoto, V. G. Pal'chikov, and V. D. Ovsiannikov: Phys. Rev. Lett. 91 (2003) 173005.

25) M. Greiner, O. Mandel, T. Esslinger, T. W. Hansch, and I. Bloch: Nature 415 (2002) 39.

26) W. Hofstetter, J. I. Cirac, P. Zoller, E. Demler, and M. D. Lukin: Phys. Rev. Lett. 89 (2002) 220407.

\footnotetext{
光トラップ (optical trapping)

原子に非共鳴なレーザー光を照射することによってで きるポテンシャルに原子を閉じ达めること.このポテン シャルは，光による原子のエネルギー準位のシフトでも あり，ライトシフトとも呼ばれている。また，正弦波の 光電場によるシフトでもあり，ACシュタルクシフトとも 呼ばれる，赤方離調の場合には，光ポテンシャルは負に なる、したがって，光ビームをレンズ等でフォーカスさ

せるだけで，強度が最も高い焦点に原子をトラップする ことが可能になる．青方離調の場合には，光ポテンシャ ルは正になるので, 光強度の弱いところにトラップされ ることになる．また，非共鳴な光を用いているからと いっても, 光の吸収はゼロではなく, 加熱やトラップロ スを伴う。

(高橋 義朗)
} 